\title{
An Analysis of Consumers’ Perception Towards Rebranding: A Study of Hero MotoCorp
}

\author{
Joyeeta Chatterjee \\ N. L. Dalmia Institute of Management Studies and Research, Mumbai, India
}

\begin{abstract}
One of the significant marketing changes in the past decade involves the dramatic increase in the variety of ways in which consumers can express their identities. A key driver of this change has been the growth of one-to-one marketing and mass customization. This trend has led many companies to rebrand and reposition their products or services focusing on functional attributes to focusing on how they fit into a consumer's lifestyle. In the recent years, we have seen a growing trend of rebranding in India such as Vodafone, Airtel, Hero MotoCorp (erstwhile Hero Honda) to media channels to across different industries. This trend has compelled several business conglomerates to rebrand and get a makeover of their products and services. These organizations, while conducting the rebranding exercise, emphasize on concentrating on the functional attributes to how they fit into a consumer's lifestyle which are received very well by business houses. By revitalizing their brands, business houses are ready to face a tough challenge in the marketplace and earn a respectable market share too. The rebranding exercise of Hero MotoCorp provides fascinating insights. The drivers and methodology adopted by the two-wheeler manufacturer which includes the makeover of the brand architecture, brand name, brand logo and the positioning with the theme of creation, renewal and re-energizing the brand are worth mentioning.
\end{abstract}

Keywords: rebranding, brand recall, consumer perception, emotional connect

\section{Introduction}

The one thing that will never change is the change itself that happens in different phases of life. Perhaps with this notion, in the world of business, even the popular brands practice change, in terms of their logos and customer perception. There are some similarities in several brands like Airtel, Vodafone, Axis Bank (erstwhile UTI Bank), Hero MotoCorp (erstwhile Hero Honda), Videocon, Air India, Kodak, Yahoo, KFC, Starbucks, Motorola, Snapdeal, and many more. All these brands have undergone rebranding exercise in the recent past with a logo change.

A brand symbolizes one of the most vital assets to a company which is personified by its name, logo, and slogan that portrays a means by which consumers identify and reminisce the brand. With the surge in market competition, various companies choose to undertake rebranding exercise thereby revitalizing themselves or get a makeover. This trend has led many companies to rebrand and reposition their products or services focusing on functional attributes to focusing on how they fit into a consumer's lifestyle. In marketing, one momentous change in the contemporary time includes the histrionic growth in the ways in which consumers can express their selves and individualities. One of the vital reasons behind such change has been the growth and

Joyeeta Chatterjee, Professor and HoD Marketing, N. L. Dalmia Institute of Management Studies and Research, Mumbai, India. 
development of unique concepts such as one-to-one marketing and mass customization, which has extended approachability to the conventional ways of self-expression such as cheering for favourite sport teams and music groups, wearing iconic brands, or developing hobbies and also familiarized an assortment of new and ground-breaking layouts where the customers can find their voices heard, e.g., the social networking sites like Twitter Handle or Facebook. This trend has compelled several business conglomerates to rebrand and get a makeover of their products and (or) services. These organizations, while conducting the exercise of rebranding, emphasize on concentrating on the functional attributes to how they fit into a consumer's lifestyle. These rebranding exercises are received very well by business houses that are of the opinion that by revitalizing their brands, they are ready to face a tough challenge in the marketplace and earn a respectable market share too.

\section{Research Gap and Problem}

Many studies were carried out on brand logos exclusively, which showcased the importance of obtaining the customers' response on logos and logo changes (Kohli, Suri, \& Thakor, 2002; Hem \& Iversen, 2004). There are couple of studies that looked directly into logo changes (Pimental \& Heckler, 2000; Walsh, Page, \& Mittal, 2006). It was found from the previous study that shoppers usually preferred no logo changes; however they accepted the brand with minor changes (Walch et al., 2006), on the contrary observed that highly brand committed users had more negative attitudes toward the brand after the logo change, whereas weakly committed customers had more favourable brand attitudes towards the change in logo. However, there are no researches as far as consumers' thoughts and reactions towards logo change are concerned. Therefore researcher proposes to study the perception of consumers towards rebranding with logo changes with this two-wheeler giant. The researcher also made efforts to understand consumers' minds especially when they are exposed to rebranding with logo changes. With that intention, the researcher proposes the rationale of the study. The rebranding exercise carried out by Hero MotoCorp provides interesting insights of the entire process of brand revitalizing by reviewing the drivers and methodology adopted by the two-wheeler manufacturer which includes the makeover of brand architecture, brand name, brand logo and the positioning with the theme of creation, renewal and re-energizing the brand.

\section{Objectives of the Study}

The exercise of rebranding may occur intentionally through a deliberate change in strategy or unintentionally from unplanned situations or even after mergers and acquisition, if the brand has outgrown its identity or has been through any kind of scandal. This study was conducted to understand the rebranding process exercised by Hero MotoCorp, after their break-up of the JV; understand the perception of two-wheeler consumers towards the brand; and learn its impact on consumers after re-branding, especially in an emerging market like India.

\section{Review of Literature}

Rebranding, which has cropped up in the last couple of decades or so, refers to repositioning or revitalizing a brand. In the recent past, it has been observed that rebranding has been an increasing phenomenon worldwide, no matter whether it is a necessity, luxury, real, or even cosmetic (Kaikati, 2003); rebranding as defined by Stern (2006) is a name changing exercise of the company or its targeting and positioning, in an attempt to attach new connotation to the corporate brand and communicate the same to the stakeholders. According to Aaker (1991), rebranding constitutes the basis for the corporate communications program and for 
the consumer's awareness and images. In the words of Stuart and Muzellec (2004), rebranding can be a result of mergers and acquisitions, whereby the company then focuses on a new image and vision. It is an exercise of creating a new name illustrating the differentiated position in the mind set of shareholders and also occupying a separate identity from its competitors (Muzellec, Doogan, \& Lambkin, 2003; Muzellec \& Lambkin, 2006). The most crucial factor in successful rebranding is to incorporate rebranding among the employees of the firm. One way to reduce any sort of anxiety among the employees is to involve them in the planning stage of creating a new name. Daly and Moloney (2004) will not only keep them motivated and but enable the organization to gain support and assurance from the employees, and familiarize them with the company's new policies and procedures. To spread the new brand message throughout various levels within the company, organization needs to strategically develop communication and training program. Moreover the organizations undertaking rebranding exercise should keep in mind that continuity and consistency is very important. Osler (2004) addressed the reasons for name changes which include mergers and acquisitions, changing business categories, an outdated name, changing brand perceptions, legal necessity or for other international language considerations.

\section{Research Methodology}

In this study, primary and secondary researches were conducted. Judgmental sampling method was used. Two focus group interviews were conducted with eight members in each group, first phase with pre-rebranding scenario discussion and the second with post-re-branding scenario. Primary research was done to understand the effects of rebranding on the consumer and the perceptual differences among the customers and non-customers. Factor analysis has been used to identify the important factors that impact the major rebranding decision using the SPSS version 20. The " $t$-test" of the hypotheses was conducted to determine the perceptions towards the "new tagline" and "the colour of the new logo" of Hero MotoCorp.

\section{Reasons for Selecting Hero MotoCorp as a Case Study}

Very few academic studies were done on rebranding. This study was conducted with an aim to have an enhanced understanding about the effect of rebranding of a leading two-wheeler brand- "Hero MotoCorp" in the consumers' minds and understand further their reactions towards rebranding and purchase intentions.

Rebranding, these days have become a common phenomenon which is increasingly taking place not only in overseas market but also in Indian markets. Hero Honda was known as one of the largest two-wheeler manufacturer across the globe. In fact the country's two-wheeler market has been defined by Hero Honda. However, as pointed out by Kaikati and Kaikati (2003) and Botterill and Kline (2007), a study on rebranding is important not because many business houses are conducting this exercise, but because of the tremendous cost involved in the process. Rebranding a conglomerate of such a repute is a vast task and the way the entire exercise was executed by Hero Group was worth considering for this study. London-based Wolff Olins-a global brand and innovation specialist firm was roped in by Hero group, to work on its new identity including the brand name, brand architecture, logo and brand positioning with a core theme of creation, renewal and re-energizing the brand. The entire re-branding exercise involved a gradual shrinkage of Honda and place "Hero" on all its products by 2014. It becomes essential for a researcher to understand the perception of customers towards this vital exercise of re-branding undertaken by Hero Group and its impact on their purchase decision. 


\section{Hero MotoCorp (Erstwhile Hero Honda)}

Hero Honda Ltd. was set up in 1984 as one of the leading two-wheeler manufacturers in India, as a joint venture (JV) between Honda Motors, Japan and Hero Cycles Ltd., India. In 2010, Honda Motors Company, Japan, decided to exit the JV after 26 years. Having more than five million strong consumer bases, Hero Honda was truly the "Desh Ki Dhadkan" (Heartbeat of the Nation) touching the hearts of millions of Indians. After the break-up of the JV, rebranding such a popular brand was a mammoth task, especially when it is required to move out of the mould of Hero Honda and launch a new horizon for itself. The new logo was revealed during the India VS England cricket series in August 2011 which aims to relate to the youth. The company also launched a new jingle "Hum Mein Hai HERO" (There is a winner in all of us) on the Independence Day of India, i.e., on August 15, 2011, with an intention to arrest the attention of maximum audience.

\section{Demographic Details}

To understand the consumers' perception towards rebranding primary data were collected from Delhi and NCR area. Two focus group discussions were held which triggered to collect the consumers' responses through structured questionnaire. The questionnaires were distributed approximately to 200 respondents from which 185 responses were retrieved but several response sheets were incomplete. For this study, only 160 valid answers were considered. The mean of the respondents' age was 32. Among the 160 respondents surveyed between 18 to 45 years, 91 percent were male and nine percent female respondents; 57 percent were graduates, 41 percent post graduates, and two percent with intermediate degrees. The respondents comprised of 12 percent of self-employed, 41 percent professionals, and the remaining 47 percent were students. As far as the income range is concerned, 58 percent were in the category below INR 3 lakhs p.a., 39 percent in the category ranging between INR 6-9 lakhs p.a., and three percent were earning above INR 9 lakhs p.a. This is displayed in Table 1.

Table 1

Details of Demographics of the Respondents of Hero MotoCorp

\begin{tabular}{|c|c|c|c|}
\hline \multicolumn{2}{|c|}{ Particulars of the respondents } & \multirow{2}{*}{$\begin{array}{l}\text { Number of respondents } \\
75\end{array}$} & \multirow{2}{*}{$\begin{array}{c}\text { Percent } \\
47\end{array}$} \\
\hline \multirow{6}{*}{ Age group } & $18-25$ & & \\
\hline & $26-35$ & 78 & 49 \\
\hline & $36-45$ & 7 & 4 \\
\hline & $46-55$ & - & - \\
\hline & Above 55 & - & - \\
\hline & Total & 160 & 100 \\
\hline \multirow{3}{*}{ Gender } & Male & 145 & 91 \\
\hline & Female & 15 & 9 \\
\hline & Total & 160 & 100 \\
\hline \multirow{4}{*}{ Educational qualification } & Intermediate & 4 & 2 \\
\hline & Graduate & 91 & 57 \\
\hline & Post graduate & 65 & 41 \\
\hline & Total & 160 & 100 \\
\hline \multirow{6}{*}{ Occupation } & Employed in a firm & 66 & 41 \\
\hline & Self employed & 19 & 12 \\
\hline & Home maker & - & - \\
\hline & Retired & - & - \\
\hline & Students & 75 & 47 \\
\hline & Total & 160 & 100 \\
\hline
\end{tabular}


(table 1 continued)

\begin{tabular}{llll}
\hline Particulars of the respondents & & Number of respondents & Percent \\
\hline \multirow{3}{*}{ Annual income } & Below 3 lakhs & 92 & 58 \\
& 3-6 lakhs & 63 & 39 \\
& 6-9 lakhs & 5 & 3 \\
& Above 9 lakhs & - & - \\
& Total & 160 & 100 \\
\hline
\end{tabular}

Source: Authors' compiled data.

\section{Data Analysis}

For better understanding, the respondents were divided into customers and non-customers. Customers comprised of 68 percent of buyers of Hero MotoCorp and non-customers comprised of 32 percent of buyers of competitor brands. It has been observed that the perception of the consumers of tangibles has increased, after rebranding. All the respondents were aware of both, old and new logos of Hero. Brand recall was high (Figure 1), but it was not necessarily due to rebranding. Brand trust is high and the legacy still continues. Brand name, tagline, and jingle were considered by the respondents as the most important parameters for the brand recall (Figure 2).

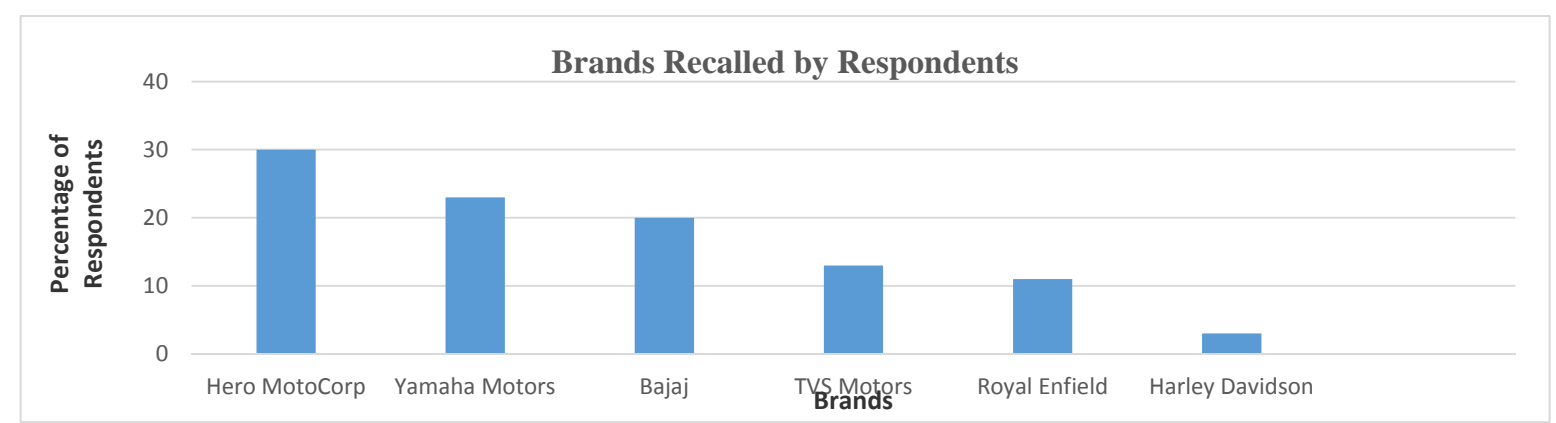

Figure 1. Brands recalled by respondents. Source: Authors’ compiled data.

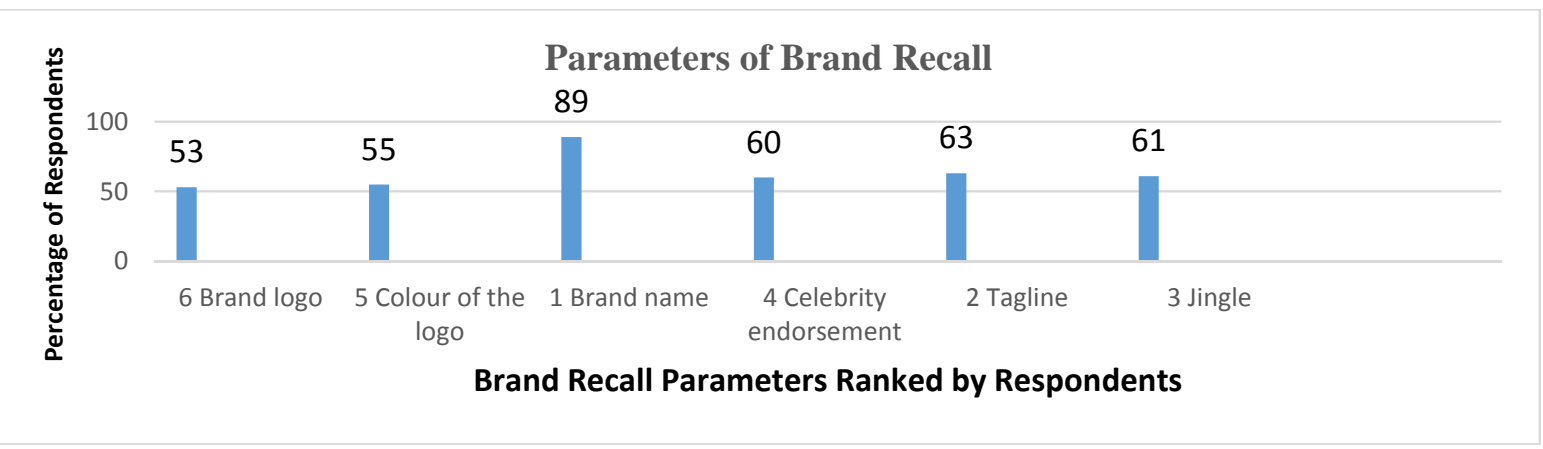

Figure 2. Parameters of brand recall. Source: Authors’ compiled data.

As far as the impact is concerned, rebranding of Hero MotoCorp brought in mixed response. Nineteen percent of the respondents agreed that rebranding made the brand "young" while 48 percent disagreed with this and 33 percent of them were indifferent. Likewise, 44 percent of the respondents found that the new logo was well launched; 33 percent did not agree with this while 23 percent neither agreed nor disagreed. As far as freshness is concerned, both customers and non-customers were of the opinion that the new logo looked fresh. Majority of non-customers found the new logo of Hero traditional, and only a negligible percentage of 
non-customers found the new logo contemporary. Regarding the tagline, 27 percent of the respondents found the new tagline marginally better while 38 percent of them found it significantly better than the older version. Nineteen percent of the respondents could not differentiate between the old and the new tagline and the remaining 16 percent of the respondents found the new tagline not good at all. Regarding the new jingle, 19 percent of the respondents found it similar to the older version of the jingle. However, 21 percent of the respondents found the new jingle significantly better and 17 percent found it marginally better than the previous jingle of the brand Hero MotoCorp (Figure 3).

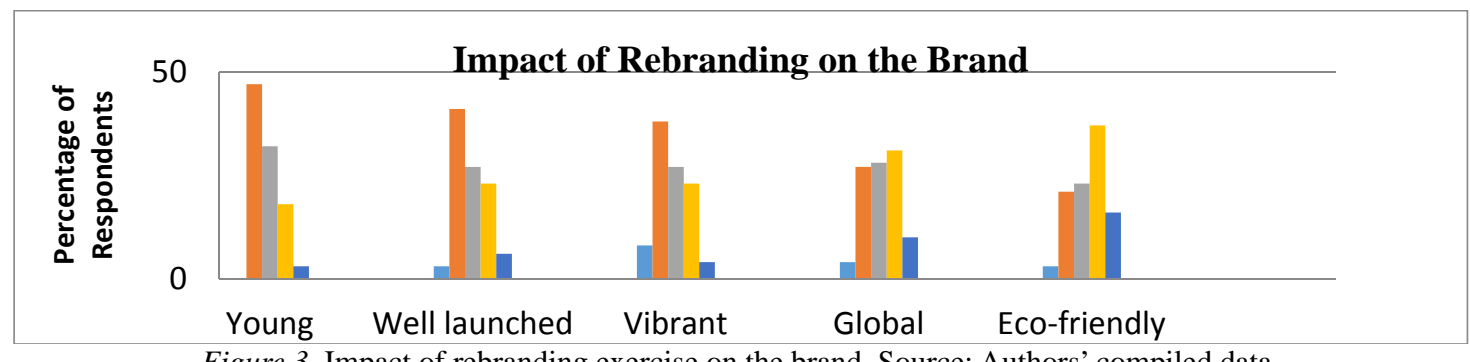

Figure 3. Impact of rebranding exercise on the brand. Source: Authors' compiled data.

Efforts were made to understand whether revitalizing a brand had any impact on the buying decision of the respondents and consequently the impact on its sales figures of the brand Hero MotoCorp. Out of 68 percent of customers of Hero MotoCorp, 16 percent purchased Hero products after rebranding, 24 percent did not purchase after rebranding, and the remaining 27 percent purchased after the rebranding exercise, but were not influenced by its rebranding. The brand's existing trust played an important role (Figure 4).

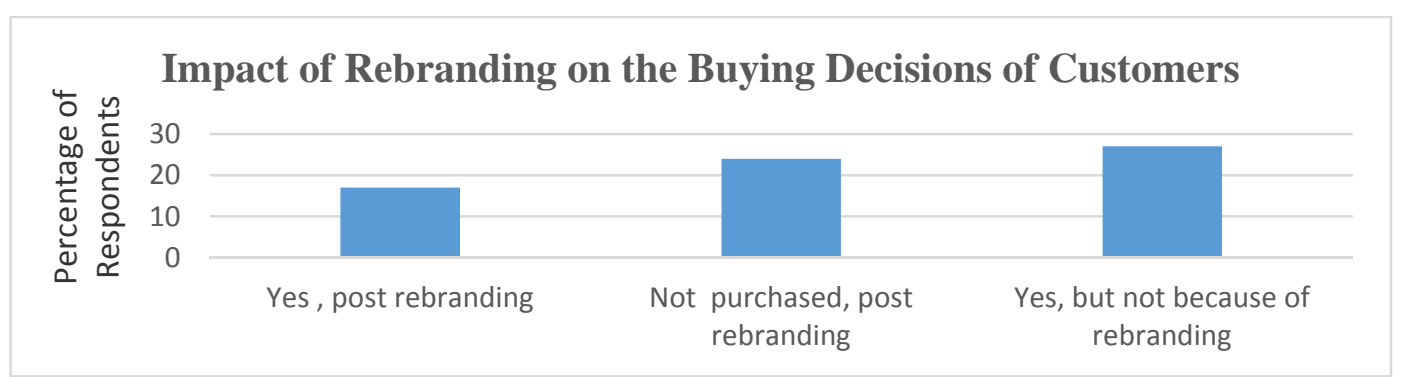

Figure 4. Impact of rebranding on the buying decisions of customers. Source: Authors' compiled data.

Efforts were made to comprehend the buying behavior of those customers who purchased Hero products influenced by rebranding. Thirty-five percent of this set of customers purchased second two-wheeler and 24 percent of them purchased Hero products/services for family members and 41 percent of this set of customers recommended Hero products/services to friends (Figure 5).

Attempt was also made to understand the behaviour of another set of customers who purchased Hero products/services after its rebranding, but their purchase was not influenced by rebranding. Forty-four percent of these customers purchased second two-wheeler of Hero and the remaining 19 percent purchased Hero products/services for family usage and other members of the household. Thirty-seven percent of customers of this category recommended Hero MotoCorp to friends/peers (Figure 6). 


\section{Purchase Behaviour of Customers of Hero MotoCorp, Influenced by Rebranding}

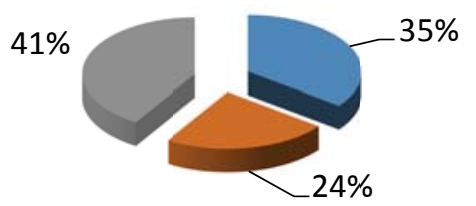

n Purchased second two-wheeler

u Purchased for family members

Figure 5. Buying behaviour of customers of Hero MotoCorp, influenced by rebranding. Source: Authors’ compiled data.

\section{Purchase Behaviour of Customers of Hero MotoCorp, Not Influenced by Rebranding}

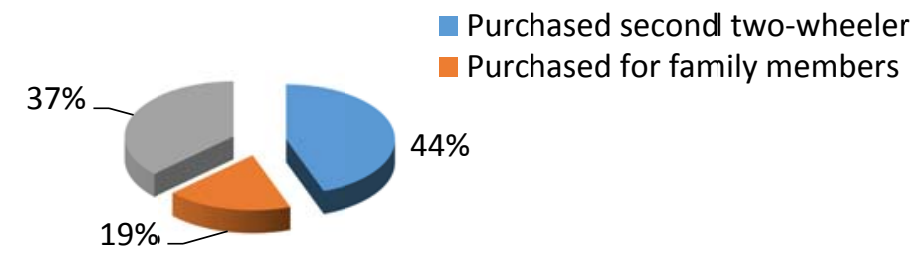

Figure 6. Buying behaviour of customers of Hero MotoCorp not influenced by rebranding. Source:: Authors’ compiled data.

A substantial portion of the buyers was influenced after rebranding, to purchase Hero products. It shows that rebranding of Hero MotoCorp could cause an increase in the sales figures. However, an interesting finding of the study is another set of substantial portion of buyers also purchased Hero products after the rebranding exercise of the company, but as pointed out, their purchase was not influenced by rebranding. High brand recall and increased trust in the brand "Hero" are the important reasons behind their purchase decision. The non-customers of Hero, however, were not influenced by rebranding at all and the rebranding exercise undertaken by the company did not impact their buying decision. In order to attract this set of customers, the researcher feels that the company needs to think of creating an effective communication program not merely to make the masses aware of the new logo or the new brand name but also about the improved services or other value additions brought in the product or service. Especially after the break-up with Honda, many respondents, especially the non-customers were apprehensive about the quality of the products. Therefore, it becomes vital for the company to remove any sort of doubts in the minds of people, after rebranding. Efforts need to be made by the "Hero MotoCorp" to maintain the same recall value which Hero Honda had once upon a time.

In order to determine the important factors that influence buying decision for a product like Hero MotoCorp, factor analysis was done using the SPSS version 20 and the result of the responses collected from Hero MotoCorp Rebranding Case is presented. SPSS version 20 has been used by the researcher for the statistical analysis.

Table 2

KMO and Bartlett's Test (Hero MotoCorp)

\begin{tabular}{lll}
\hline \multicolumn{2}{l}{ Kaiser-Meyer-Olkin measure of sampling adequacy } & 0.566 \\
\hline \multirow{3}{*}{ Bartlett's test of sphericity } & Approx. Chi-Square & 1.52 .169 \\
& $\mathrm{df}$ & 2.8 \\
& Sig. & 0.000 \\
\hline
\end{tabular}

The KMO test measures the sampling adequacy which falls in the acceptable range with a value of 0.566 . 
Eight variables such as price, driving safety, fuel efficiency, comfort, brand image, style, resale as well as customer services were selected for the test. Barlett's test of spericity is significant, thus the hypothesis that the inter-correlation matrix involving these eight variables is an identity matrix is rejected. Thus from the perspective of Bartlett's test, factor analysis is feasible.

Table 3

(Hero MotoCorp) Rotated Component Matrix ${ }^{a}$

\begin{tabular}{llll}
\hline & \multicolumn{2}{c}{ Component } \\
\cline { 2 - 4 } & 1 & 2 & 3 \\
\hline Price & -0.013 & -0.030 & 0.892 \\
Driving safety & 0.718 & -0.289 & 0.164 \\
Fuel efficiency & 0.245 & 0.091 & 0.782 \\
Comfort & 0.752 & 0.143 & -0.036 \\
Brand image & 0.234 & 0.775 & 0.078 \\
Style & 0.015 & 0.863 & -0.029 \\
Resale & 0.515 & 0.318 & 0.136 \\
Customer service & 0.687 & 0.288 & 0.142 \\
\hline Note. Extaction
\end{tabular}

Note. Extraction Method: Principal Component Analysis. Rotation Method: Varimax with Kaiser Normalization. a. Rotation converged in five iterations.

In the rotated factor solution, variables 2, 4, 7, and 8 load significantly on factor 1; variables 5 and 6 load significantly on factor 2; variables 1 and 3 load significantly factor on 3.

Table 4

Factors That Influence Buying Decision after Rebranding of Hero MotoCorp

\begin{tabular}{lll}
\hline Sl. No. & Loading variables & Significant factor's name \\
\hline & a. Driving safety $(0.718)$ & \\
1. & b. Comfort $(0.752)$ & Product attributes \\
& c. Resale $(0.515)$ & \\
d. Customer service $(0.687)$ & Brand image \\
2. & e. Brand image $(0.755)$ & \\
3. & g. Style $(0.863)$ & Economy factors \\
\hline
\end{tabular}

The results of factor analysis show the important factors that influence customers to either continue with the brand or purchase the services from the brand in question, are driving safety, comfort, resale value, and customer services, followed closely by brand image and style and economy factors like price and fuel efficiency. This is exhibited in Table 4 above.

To understand better the mindset of the customers, few open ended questions were asked to the customers, i.e., how likely they are to consider Hero products in their next purchase. A summation of the response is presented below in Table 5 . 
Table 5

Suggestions Given by Customers of Hero MotoCorp

\begin{tabular}{|l|l|l|}
\hline Nature of response & Comments of respondents & Observation \\
\hline Positive & $\begin{array}{l}\text { More focus should be on technical changes and outlook. } \\
\text { Focus on style as well as engine, especially the BHP of bikes if we } \\
\text { compare Karizma to Pulsar 220. } \\
\text { Company must focus on producing stylish bikes and be competitive } \\
\text { enough to TVS Apache and Bajaj Pulsar. Most of the Hero Two } \\
\text { Wheelers are of strong body parts but it fails to attract youth by its } \\
\text { stylish look. } \\
\text { Hero has been doing a very good job to improve its brand image by } \\
\text { its amazing advertisement. It can further improve its brand image } \\
\text { by providing better services. }\end{array}$ & Reasonable good suggestions \\
\hline Negative & $\begin{array}{l}\text { Advertisements were unable to connect with the audience. The } \\
\text { company should use new age media like the social networks etc. } \\
\text { Logo does not have clarity about the brand. It needs to be } \\
\text { improved. } \\
\text { Company does not have aggressive promotion policy. } \\
\text { Tagline is not appealing. } \\
\text { People still have the “Honda” tag in their minds. There’s no } \\
\text { sufficient push by the company to increase the recall of "Hero." } \\
\text { Customer service should be improved. }\end{array}$ & $\begin{array}{l}\text { Advertising strategy of the } \\
\text { company needs to be highlighted. } \\
\text { Brand connect to be improved. }\end{array}$ \\
\hline Neutral & $\begin{array}{l}\text { Quality, price, and service are the most important factors which the } \\
\text { customers always look to buy any product. Re-branding plays least } \\
\text { role to improve the sales of a product and also to attract the new } \\
\text { and old customers in the long run. }\end{array}$ & $\begin{array}{l}\text { Quality of the products cannot be } \\
\text { compromised. After rebranding, } \\
\text { customer expects an improved } \\
\text { version of the product }\end{array}$ \\
\hline Special remark & $\begin{array}{l}\text { Focus on technology. Do not let the quality of flagship brands } \\
\text { deteriorate. Maintain or improve technology by bringing in a new } \\
\text { technology partner. }\end{array}$ & \\
\hline
\end{tabular}

Source: Authors' compiled data.

The table above exhibits valuable suggestions given by the respondents, related to the product, marketing of the products as well as the customer services extended by Hero MotoCorp, especially to its customers. The customers of Hero were not in favour of the new logo that was developed after rebranding. The respondents of this study felt after rebranding, the company needs to focus on technology and continue to manufacture quality products. Also the brands needs to stay connected with customers through social networks and practice aggressive marketing. The researchers too observed the respondents feedback. According to the respondents, the new logo of Hero MotoCorp does not bring clarity about the brand; therefore the researchers feel that Hero Group may work upon to improve its new logo.

\section{Conclusion}

While conducting this study, few challenges were identified which are usually faced by companies undergoing rebranding exercise-firstly, the strategies to be implemented with important brand elements like jingle, slogan, logo, the colour of the logo, the brand name itself, and the style of writing the name of the brand; secondly the intensity of conversation the brand would engage with those who oppose to changes due to rebranding and thirdly the communication strategy to craft new values in the existing brand. It was an immensely challenging task to restyle a popular brand like Hero MotoCorp since it was necessary to move the shield of Honda to a totally new horizon.

Regarding the overall perception, after rebranding, Hero MotoCorp definitely brought in noticeable changes and value additions in their products and services. However, they need to communicate well to the 
masses the new improvements introduced by Hero MotoCorp in their products/services. Non-customers are not associated with the product and hence they carried a withdrawn approach towards this rebranding exercise. If the communication is done well by the company while conducting the rebranding exercise, it helps the masses, both customers and non-customers, to build a better perception about the brand. They can also highlight other crucial brand elements in their marketing communication program. The researchers also feel that the company may track the purchase behavior of the customers and accordingly design an incentive oriented promotional scheme for the loyal customers or repeat purchasers or even for those who recommend Hero products.

\section{References}

Aaker, D. A. (1991). Managing brand equity: Capitalizing on the value of a brand name. New York: The Free Press.

Botterill, J., \& Kline, S. (2007). From McLibel to McLettuce: Childhood, spin \& rebranding. Society and Business Review, 2(1), 74-97.

Daly, A., \& Moloney, D. (2004). Managing corporate rebranding. Irish Marketing Review, 17(1/2), 30-36.

Hem, L. E., \& Iversen, N. M. (2004). How to develop a destination brand logo: A qualitative and quantitative approach. Scandinavian Journal of Hospitality \& Tourism, 4(2), 83-106.

Kohli, C., Suri, R., \& Thakor, M. (2002). Creating effective logos: Insights from theory and practice. Business Horizons, 45(3), 58-64.

Kaikati, J. G. (2003). Lessons from Accenture’s 3Rs: Rebranding; restructuring \& repositioning. Journal of Product \& Brand Management, 12(7), 477-490.

Kaikati, J. G., \& Kaikati, A. M. (2003). A rose by any other name: Rebranding campaigns that work. Journal of Business Strategy, 24(6), 17-23.

Muzellec, L., \& Stuart, H. (2004). Corporate makeovers: Can a Hyena be rebranded? Journal of Brand Management, 11(6), 472-482.

Muzellec, L., Doogan, M., \& Lambkin, M. (2003). Corporate rebranding-an exploratory review. Irish Marketing Review, 16, 31-40.

Muzellec, L., \& Lambkin, M. (2006). Corporate rebranding: Destroying, transferring or creating brand equity? European Journal of Marketing, 40(7/8), 803-824.

Osler, R. (2004). Making the case for a new brand name. Journal of Brand Management, 12(2), 81-92.

Pimentel, R., \& Heckler, S. (2000). Changes in logo designs: Chasing the elusive butterfly curve. Working Paper, 1-24. Retrieved from http://www.yaffecenter.org/yaffe.nsf/a9e6f4141273da118525685d005a88a2/98f0cc e0731756c6852568ff00589361

Stern, B. B. (2006). What does brand mean? Historical-analysis method and construct definition. The Journal of the Academy of Marketing Science, 34(2), 216-223.

Walsh, M. F., Page, K. L., \& Mittal, V. (2006). Logo redesign and brand attitude: The effect of brand commitment. ACR 2006 Conference, September Orlando, Florida. 